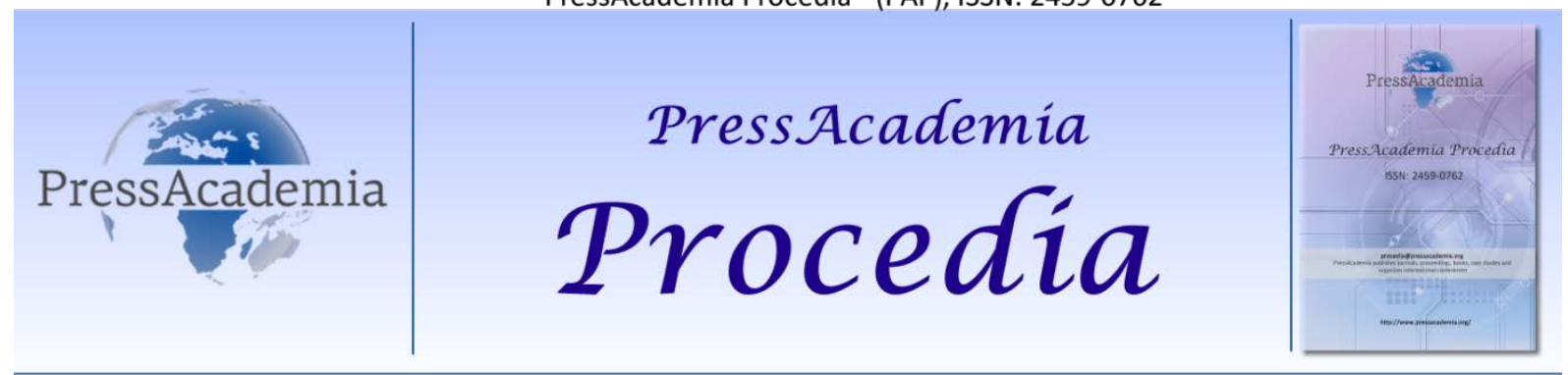

Global Business Research Congress (GBRC), May 26-27, 2016, Istanbul, Turkey.

\title{
ACCOUNTING PERCEPTION OF BUSINESS STUDENTS TO DESCRIBE BY HELPING METAPHORS
}

DOI: 10.17261/Pressacademia.2016118650

\author{
Mursel Guler ${ }^{1}$, Ahmet Agca ${ }^{2}$, Dursun Boz ${ }^{3}$ \\ ${ }^{1}$ Dumlupınar Üniversitesi, mursel.guler@dpu.edu.tr \\ 2Dumlupınar Üniversitesi, ahmet.agca@dpu.edu.tr \\ ${ }^{3}$ Dumlupınar Üniversitesi, dursunboz@hotmail.com
}

\begin{abstract}
This study aims at determining "Accounting" metaphors perceptions of the Faculty of Economics and Administrative Sciences students who have attended accounting classes. It was applied classes in Kütahya, Turkey during the 2014-2015 Academic Year on the the Dumlupinar University, Faculty of Economics and Administrative Sciences students who have received accounting education. The study was performed on a group of 200 students from the 3rd and 4th grade students with accounting training who are attending school at present. The students were included on volunteer basis. The participants were given survey forms with some sentences with gaps which are supposed to be completed by the students, such as;

"An accountant is like ...................................................., because ..............................................................."

"An independent accountant is like ...................................., because ..........................................................."

"A certified public accountant is like , because .".

The results of these surveys were used in order to find out the metaphors the students develop concerning the Accounting lessons and the common features of these metaphors. In evaluation of the data received from the surveys content analysis method was used in compliance with the qualitative research pattern. Metaphors developed by the students concerning the Accounting lessons were categorized in ten groups.
\end{abstract}

Keywords : Accounting education, metaphor, accountant

JEL Codes : M00, M40, M41

\section{IŞLETME ÖĞRENCILERININ MUHASEBE ALGILARININ METAFORLAR YARDIMIYLA ANLATILMASI}

\section{ÖZET}

Bu çalışmanın amacı, Dumlupınar Üniversitesi I.i..B.F. öğrencilerinden Muhasebe Eğitimi almış öğrencilerin “Muhasebe” metaforları algılarını belirlemektir. Çalışma 2014-2015 eğitim-öğretim yılında Kütahya ilinde Dumlupınar Üniversitesi i̇.i.B.F. öğrencilerinden Muhasebe Eğitimi almış öğrencilere uygulanmıştır. Araştırma bu üniversitede eğitimine devam eden ve Muhasebe Eğitimi alan 3 . ve 4 . sınıf öğrencileri içerisinden 200 kişilik bir grup üzerinde yürütülmüştür. Öğrencilerin araştırmaya dahil edilmesinde, gönüllülük esası dikkate alınmıştır. Araştırma kapsamındaki öğrencilere,

"Muhasebeci.............................benzer; çünkü ...................."

"Serbest Muhasebeci..................benzer, çünkü....................."

"Yeminli Mali Müşavir...............benzer; çünkü......................."

Biçiminde eksik bırakılmış bir cümlenin yer aldığı anketler dağıtılmıştır. Bu anketler aracılığı ile öğrencilerin Muhasebe Eğitimi dersine ilişkin olarak geliştirdikleri metaforlar ve bu metaforların ortak özellikleri belirlenmeye çalışılmıştır. Elde edilen anket verilerin değerlendirilmesinde nitel araştırma desenine uygun olarak içerik analizi yöntemi kullanılmıştır. Öğrencilerin Muhasebe Eğitimi dersine ilişkin olarak geliştirdikleri metaforlar 10 kategoriye ayrılmıştır.

Anahtar Kelimeler: Muhasebe eğitimi, metafor, muhasebeci

JEL Kodları: M00, M40, M41 


\section{GiRiş}

Metafor; Türk Dil Kurumu Türkçe sözlüğünde etimolojik kökeni Fransızcadan métaphore karşılık olarak "mecaz" olarak isimlendirmektedir. Olgubilim (metafor) Bir şeyi başka bir şeye benzeterek anlatırken kullanılan unsurdur.

Metafor, bilgi veya benzetme sonucu gerçek anlamının dışında kullanılan bir kavramdır. Ad değişimi olarak da bilinir. Mecâz sanatı, anlatımı daha etkili kılmak ve söze canlııı kazandırmak amacıyla yapılır. Söze güzellik, güçlülük, canlılık, zarafet, derinlik veya genişlik verir. (Morgan, 1998, s.454)

Olgubilim(fenomenoloji, metafor) deseni farkına vardığımız fakat derinlemesine ve detaylı anlayışa sahip olmadığımız olgulara odaklanmaktır. Olgular yaşanılan çevrede olayları, deneyimleri, algıları, yönelimleri, kavramlarla karşımıza çıkmakta olup, günlük yaşantımızın bir parçasıdır. Fakat bu aşinalık, olguları tam olarak anladığımız anlamına gelmez. Bazen yabancısı olmadığımız bazen de kavrayamadığımız olguları araştırmak için olgubilim (fenomenoloji) uygun bir araştırma zemini sağlar. (Yıldırım ve Şimşek, 2005, s.72).

Metafor bir şeyi, başka bir şey açısından temsil eden düşünceyi etkileyen ve karşılaşılan tecrübeyi ifade eder (Zaltman, 2004, s.257)

\section{LITERATÜR TARAMASI}

Metafor ilk kez 1980'de Lokoff ve Johnson'un "Metofors Welive By" isimli çalışmalarında "Metafora bilişsel, dikey bakış" olarak geliştirilmiştir. Metafor kavramı; 1980 yılına kadar söz sanatı olarak kabul edilerek edebiyat ve dilbilim çalışmaları sınırlarında ele alınırken, 1980 yılında ortaya atılan “Çağdaş Metafor Teorisi”nin etkisiyle disiplinler arası çalışmaların odağına yerleşmiştir (Döş, 2010, s.607).

Birçok düşünür metaforu "bir şeyin başka bir şeye benzetilerek anlatılmaya çalışılması" olarak tasvir etmekte ve Türk edebiyatındaki mecaz, teşbih ya da istiare kavramlarının metafor kelimesinin yerine kullanıldı̆̆ını söylemektedir (Sekman, 2002, s.210).

Olgubilim ile insanların gizli duygu ve düşünceleri meydana çıkarılıp söylenen ile kastedilen arasındaki ayrım ortadan kaldırılabilinir (Zaltman, 2008, s.43).

Lakoff ve Johnson metaforu; birçok alanda ve günlük konuşmalarda kullanıldığını, hatta insanların düşünce biçimlerini belirleyebildiği savunmuştur. Metaforsuz düşünce olamayacağı temelinden hareketle kelime anlamında, bizi yeni dünyalara götürecek, yeni bir şey söyleyecek ya da yeni bir bakış açısı getirebilecek her duygu ve düşüncenin metaforik olduğunu iddia etmektedirler. Bu savlarından dolayı istiarelerin yeri geldiğinde metaforik bir işlem görebileceği, fakat her metaforun bir istiare olarak değerlendirilmemesi sonucu çıkmaktadır (Lakoff ve Johnson 2005, s.11).

Olgubilim soyut konuların; somut ifadelerle kavramsal zihinsel haritalar oluşturmaktır. Böylece karışık olayların hem anlatılması hem de anlaşılması kolaylaşmaktadır (Akdemir, 2009, s.323).

Metaforun en önemli özelliği; odaklanılan olguyu en sade ve serbest haliyle elde edebilmek için geçici olarak var olan tüm ön kabullerimizi, öğretilerimizi, duygu ve düşüncelerimizi veya varsayımlarımızı bir kenara bırakmaktır (Sanders, 1982, s.355)

Metaforlar, bir şeyin bir başka şey tarafından temsil edilmesi, hayatımızın belli bir açısını nasıl gördüğümüzü ifade etmemize yardımcı olur. Bu yüzden, kimlik, kişilik ve diğer insanların önemi açısından metafor oldukça önemlidir. Metaforlar insan zihninin mekanizmasını uyarırlar. Bir değerlendirmeye göre, konuştuğumuz her dakika hemen hemen altı metafor kullanırız. Beyin resimleme teknolojileri sayesinde, araştırmacılar metaforun nöronsal temelini daha iyi anlamaktadırlar. Metaforlar sayesinde olayları yorumlarız ve bu olaylardan anlam çıkarırız. Hayal gücünün motoru metafordur. Metaforlar sayesinde bilinçaltındaki duygu ve düşünceleri su üstüne çıkarabiliriz (Zaltman, 2004, s.71)

Bir şeyi metaforla anlatmak "sihir yapmak" gibidir. Bilimsel ya da teknik konuları anlamakta zorlanmamız, dikkatimizi çabuk kaybetmemiz, konuların zorluğundan çok anlatım dilinin soyut olmasındandır. Dil ne kadar 
soyut olursa anlaşılması o kadar zorlaşır. Eğer söylediklerimizi bizi dinleyenlere anlatmak istiyorsak kullandığımız dilin hislerimize, sezgilerimize seslenmesi gerekir. (www.temelaksoy.com)

Yob (2003,s.134)'de vurguladığı gibi: "Temelde metafor, bahse konu olgunun kendisi değildir, onun yalnızca bir sembolüdür. Eğer bu olgunun kendisi olsaydı, metafora ihtiyaç olmazdı. Bu sebepten dolayı, metafor sözü edilen olgudan farklıdır ve bu olguya ait çok güçlü bir görünüş ifade etse de çoğu zaman ondan daha azdır. Bu durumun telafisi için birçok metaforun işe koşulması gerekir. (Saban, 2008, s.461)

Metafor araştırmalarında veri toplama aracı olarak yüz yüze görüşmelerden faydalanılır. Araştırmacılar, gerçekleşmiş olayların anlamlarını ortaya çıkartmak için etkileşim, esneklik ve sondalar yoluyla irdelemesi gerekir. Görüşülen insanlarla güven ve karşılıklı anlayışa dayalı etkileşim ortamı yaratılmalı ve bu ortam içinde insanların kendilerinin bile farkında olmadıkları ya da düşünmeye değer bulmadıkları yaşantıları ve bu yaşantılarının anlamları gün yüzüne çıkarılabilir. Metafor araştırmaları insanlarla yoğun etkileşim gerektirdiği için uzun ve zahmetlidir. Bu görüşmelerin sonucunda çıkan anlamları görüşülen kişiye teyit ettirme fırsatı olduğundan araştırmanın geçerliliği ve güvenirliliği artmaktadır (Yıldırım ve Şimşek, 2005, s.75).

\section{VERI VE YÖNTEM}

Araştırma için veri toplama aracı belirlenirken, metafor belirlenmesine yönelik ulusal ve uluslararası araştırmalar incelenmiştir. Incelemeler neticesinde metafor belirlemeye yönelik araştırmalarda cümle tamamlamayla açık uçlu cümleler kullanıldığı görülmüştür. Neticede araştırmada "muhasebeyi......... benzetiyorum; çünkü.................","mali müşaviri........ benzetiyorum; çünkü ................" yeminli mali müşaviri......... benzetiyorum; çünkü ................" cümlelerinin yazılı olduğu bir form verilmiş, öğrenciler çalışmayla ilgili bilgilendirilmiş ve öğrencilerin bu formları doldurmaları istenmiştir.

Araştırma nitel araştırmalarda sıklıkla kullanılan içerik analizi kullanılmıştır. Belli kurallar dahilinde yapılan kodlamaların, metnin bazı sözcükleri ile daha küçük kategorilere ayrıldığı bir uygulamadır (Büyüköztürk, 2010).

Araştırmada öğrencilerin oluşturdukları metaforlar incelenmiş, uygun olmayanlar elenmiş ve metafor kategorileri oluşturulmuştur.

\section{BULGULAR VE TARTIŞMA}

Araştırmada 200 işletme öğrencisinden muhasebe, mali müşavir ve yeminli mali müşavir için metafor belirlemeleri istenmiştir. Muhasebe için 122 öğrencinin cevapları 72 metafor, mali müşavir için 122 öğrencinin 72 metafor, yeminli mali müşavir için 103 öğrencinin 78 metafor ürettiği gözlenmiştir.

Tablo 1: Frekans Değerleri En Yüksek Metaforlar

\begin{tabular}{|c|c|c|c|c|c|}
\hline \multicolumn{2}{|c|}{ Muhasebe } & \multicolumn{2}{c|}{ Mali Müşavir } & \multicolumn{2}{c|}{ Yeminli Mali Müşavir } \\
\hline Metafor Adı & Frekans & Metafor Adı & Frekans & Metafor Adı & Frekans \\
\hline Para & 15 & Para & 6 & Para & 8 \\
\hline Kaos - Karmaşıkık & 7 & Babam & 4 & Para Babası & 6 \\
\hline Matematik & 7 & Zengin iş adamı & 3 & Tecrübeli Akademisyen & 5 \\
\hline Bulmaca & 6 & Kasa & 3 & Kasa & 3 \\
\hline Hesap Makinesi & 4 & Memura & 3 & Doktora & 3 \\
\hline
\end{tabular}

Tablo 1.'de en çok tekrar eden metaforlar verilmiştir. Muhasebe, Mali Müşavir ve Yeminli Mali Müşavir için en çok kullanılan metafor Para olarak belirlenmiştir. Tablo da en çok tekrar eden metaforlar belirlenmiş ve listelenmiştir. Daha sonraki aşamada metaforlar için öğrencilerin yaptığı açıklamadan yola çıkarak metaforlar kategorik olarak tasniflenmiştir. Muhasebe için 8, mali müşavir için 7 , yeminli mali müşavir için 7 kategori belirlenmiştir. 


\section{Muhasebe Kategorilerinin Analizi}

\section{Belirsizlik - Karmaşıklık}

Öğrenciler bu kategoride muhasebe için toplam 33 metafor oluşturmuşlardır. Öğrenciler bu kategorideki metaforları oluştururken muhasebeyi karmaşık ve anlaması zor bir kavram olarak algılamışlardır. Bunda aldıkları muhasebe derslerindeki zorlanmalar etkili olabilir. Muhasebe kavramı için en çok metafor toplanan kategoridir.

Belirsizlik - Karmaşıklık kategorisine baktığımızda Kaos - Karmaşıklık (7), Bulmaca (6), Labirent (3), Ağaç (2), Bakkal Defteri (2), Kadınlar (2), Makine (2), Boş Bir (1), Kutu Boş Çerçeve (1), Boş Levha (1), Çıkmaz Sokak (1), Erkekler (1) Düğüm Türk Kızları (1), Anlaşılmayan Bir Şey (1), Bir Hiç (1). Aşağıda bu kategoriye ait bazı öğrenci cevapları verilmiştir.

Muhasebe kaosa benzetirim; çünkü bir sürü karmaşa ve akıl zorlayıcı eylemler var.(Katılımcı 81, erkek, yaş 24)

Muhasebeyi karmaşaya benzetirim; çünkü anlaşılması zor bir ders. (Katılımcı 15, bayan, yaş 21).

Muhasebeyi karmaşaya benzetiyorum; çünkü çok karışık ve herhangi bir dersi kaçırdığın zaman toparlamak zor olur. Konular birbiriyle bağlantılıdır.(Katılımcı 113, bayan, yaş 22)

Muhasebeyi labirente benzetiyorum; çünkü bana göre muhasebe çok karmaşık ve zor geliyor. (katılımcı 39 , bayan, yaş 20)

Muhasebeyi labirente benzetiyorum; çünkü içinden uğraşsak ta çıkamıyoruz adeta boğuluyoruz. (Katılımcı 88, bayan, yaş 21)

Muhasebeyi bakkal defterine benzetiyorum; çünkü o kadar karışık ki bir şey anlamıyorum. (Katılımcı 121,bayan, yaş 23)

Muhasebeyi bakkal defterine benzetiyorum; çünkü köklü ve birden fazla kolları olan ve bir o kadar da karışık bir alan. (Katılımcı 111, bayan, yaş 22)

\section{Finansal Araç ve Gereçler}

Öğrenciler bu kategoride muhasebe için 24 metafor oluşturmuşlardır. Bu kategorideki metaforlar oluşturulurken öğrenciler finansal araç ve gereçleri dikkate aldıkları gözlenmiştir.

Finansal Araç ve Gereçler kategorisine bakıldığında 24 metafor 9 başıı altında toplanmıştır. Bunlar Para (15), Borç ve Alacak(2), Risk (1), Para Sayma Makinesi (1), Mali Yönetim (1), Hesaplar(1), Denetim (1), Her şekil de Analiz (1), Defter ve Kayıt (1), Aşağıda bu kategoriye ait bazı öğrenci cevapları verilmiştir.

Muhasebeyi paraya benzetiyorum; çünkü parayla ilgileniyor. (Katılımcı 10, bayan, yaş 21)

Muhasebeyi paraya benzetiyorum; çünkü hep hesap ve parayla ilgilenen bir dal (Katılımcı 11, bayan, yaş 21)

Muhasebeyi paraya benzetiyorum; çünkü muhasebe işleri genelde parayla dönmektedir. Bir ticari mal alınır, bina falan alınır, bunun girdisi çıktısı ödemesi olur. (Katlımcı 17, bayan, yaş 21)

Muhasebeyi paraya benzetiyorum; çünkü gelir giderle alakalı bir iş olduğu için paraya benzetiyorum. (Katılımcı 19 , bayan, yaş 21)

Muhasebeyi mali yönetime benzetiyorum; çünkü muhasebe olmadan herhangi bir yerin parasal açıdan yönetilmesi mümkün değildir. (Katlımcı 82, bayan, yaş 22)

Muhasebeyi para sayma makinesine benzetiyorum; çünkü para olmasa muhasebe olmaz, muhasebe olmasa paranın anlamı olmaz. (Katılımcı 93, erkek, yaş 23)

\section{Sayısal Kavramlar}

Öğrenciler bu kategoride muhasebe için 17 metafor oluşturmuşlardır. Bu kategorideki metaforlar oluşturulurken öğrencilerin muhasebeyi sayısal ifadelerle algıladıkları gözlenmiştir. 
Sayısal Kavramlar kategorisine bakıldığında 17 metafor 4 başlık altında toplanmıştır. Bunlar Matematik (7), Hesap Makinesi (4), Zeka Küpü (3), Sayılar Düzeni (3) Aşağıda bu kategoriye ait bazı öğrenci cevapları verilmiştir.

Muhasebeyi matematiğe benzetiyorum; çünkü hep sayısal işlemlere yer veriliyor. (Katılımcı 28, erkek, yaş 23)

Muhasebeyi matematiğe benzetiyorum; çünkü sayılarla çok ilgilenen bir bilim. (Katılımcı 73, erkek, yaş 23)

Muhasebeyi matematiğe benzetiyorum; çünkü sayılardan oluşması ve matematik problemleri gibi alış veriş sonucu oluşan bir dersi anlattığı için. (Katılımcı 75, bayan, yaş 23)

Muhasebeyi matematiğe benzetiyorum; çünkü bir sürü hesap var. (Katılımcı 92, bayan, yaş 21)

Muhasebeyi zeka küpüne benzetiyorum; çünkü birden çok renk var yani konu var ama düzenlemesi zaman alan zeka ve beceri gerektirir. (Katılımcı 91, bayan, yaş 21)

Muhasebeyi sayılar düzenine benzetiyorum; çünkü bilanço, fon akım vb. bakarak şirketler hakkında bilgi sahibi olup hisse senedi alıp satıyorum. (Katılımcı 45, erkek, yaş 22)

\section{Korku - Nefret}

Öğrenciler bu kategoride muhasebe için 17 metafor oluşturmuşlardır. Bu kategorideki metaforlar oluşturulurken öğrencilerin muhasebeyi korktuğu ve nefret ettikleri ifadelere benzettikleri gözlenmiştir.

Korku - Nefret Sayısal Kavramlar kategorisine bakıldığında 15 metafor 13 başlık altında toplanmıştır. Bunlar Eziyet (3), Muhasebe hocam (2), Korku Filmi (1), Kötü Bir Ders (1), Canavar (1), Galatasaray (1), Gereksiz (1), Sahtekar İş Adamı (1), Çince (1), İspiyoncu (1), Tilki (1),Bir Sürü Hesap Olana kitaplar (1).Korku - Nefret kategorisine ait bazı öğrenci cevapları verilmiştir.

Muhasebeyi eziyete benzetiyorum; çünkü sıkıcı ve zor. (Katılımcı 46, bayan, yaş 23).

Muhasebeyi eziyete benzetiyorum; çünkü işin içinden çıkılmıyor. (Katılımcı 70, bayan, yaş 21).

Muhasebeyi korku filmine benzetiyorum; çünkü muhasebe denince tüylerim ürperiyor. (Katılımcı 122, bayan, yaş 22)

Muhasebeyi canavara benzetiyorum; çünkü anlamıyorum, sevmiyorum açık konuşmak gerekirse 1. sınıfta aldığım muhasebe eğitimi hiç iyi değildi. (Katılımcı 115, bayan, yaş 20)

Muhasebeyi galatasaraya benzetiyorum; çünkü onu da sevmem. (Katılımcı 69, bayan, yaş 20)

Muhasebeyi tilkiye benzetiyorum; çünkü sinsidir, kurnazdır(Katılımcı 43, erkek, yaş 26)

\section{Beğeni - Sevgi}

Öğrenciler bu kategoride muhasebe için 12 metafor oluşturmuşlardır. Bu kategorideki metaforlar oluşturulurken öğrencilerin metaforları sevgi - beğeni oluşturdukları gözlenmiştir.

Sevgi - Beğeni kategorisine bakıldığında 12 metafor 11 başlık altında toplanmıştır. Bunlar Hayat (2), Akademisyen (1), İnsanın Kalbi (1), Gökyüzü (1), Temel Bir Ders (1), Aile (1), Mercedes (1), Müzik Aleti (1), Lunapark (1), Tamirci (1), Komando (1). Sevgi - Beğeni kategorisine ait bazı öğrenci cevapları verilmiştir.

Muhasebeyi hayata benzetiyorum; çünkü bazen zor olabiliyor. Ama insan kurallarını öğrendikçe başarılı olabilir. Hayat gibi inişli çıkışı bir yol muhasebe bence(Katılımcı 2, erkek, yaş 24)

Muhasebeyi hayata benzetiyorum; çünkü hayattaki her şey bir nevi böyle işliyor, herkesin kendine göre bir muhasebe yapması gerekir. En küçük birimden en büyüğüne kadar.(Katılımcı 83, bayan, yaş 22)

Muhasebeyi insan kalbine benzetiyorum; çünkü muhasebeyi işletmenin kalbi olarak görüyorum. İşletmenin devamlılığı için muhasebe en önemli etkendir. (Katılımcı 38, bayan, yaş 21)

Muhasebeyi gökyüzüne benzetiyorum; çünkü yeryüzünün enerji almasını sağlayan ve yeryüzünü oksijenle kaplayarak, canlıların yaşamına olanak sağlayan bir kaynaktır. (Katılımcı 51, erkek, yaş 25) 
Muhasebeyi gökyüzüne benzetiyorum; çünkü bana basit ve eğlenceli geliyor. (Katılımcı 18, bayan, yaş 23)

Muhasebeyi gökyüzüne benzetiyorum; çünkü işletmenin ekonomik düzenini defter tutması bunlar bir nevi tamir yenileme olarak görüyorum. (Katılımcı 77, erkek, yaş 24)

\section{Yiyecek}

Öğrenciler bu kategoride muhasebe için 12 metafor oluşturmuşlardır. Bu kategorideki metaforlar oluşturulurken öğrencilerin metaforları sevgi - beğeni oluşturdukları gözlenmiştir.

Yiyecek kategorisine bakıldığında 8 metafor 8 başlık altında toplanmıştır. Bunlar Suşi Çubuğu ile Suşi Yemeye Çalışan Türk (1), Yemek Yemek (1), Kabartma Tozu (1), Sağlıklı ama Tadı Kötü Yiyecek (1), Karnabahar (1), Hindistan Cevizi (1), Dikenli İncir (1), Salata. Yiyecek kategorisine ait bazı öğrenci cevapları verilmiştir.

Muhasebeyi salataya benzetiyorum; çünkü çok karışık geliyor bana, içeriği geniş çok fazla hesap ve detay var; ama tadı tuzu olmayan bir salata. (Katılımcı 52, bayan, yaş 25).

Muhasebeyi yemek yemeye benzetiyorum; çünkü yemek yemeden yaşayamayız. (Katılımcı 58, erkek, yaş 28).

Muhasebeyi kabartma tozuna benzetiyorum; çünkü ne kadar eklersen o kadar kabarır. Bilgi yükledikçe genişler. (Katılımcı 47, bayan, yaş 24).

Muhasebeyi hindistan cevizine benzetiyorum; çünkü dışı sert, içindeki lezzetli şeye ulaşmak için dışındaki kabuğu kırmak için uğraşmak gerekir. (Katılımcı 44, bayan, yaş 24).

Muhasebeyi dikenli incire benzetiyorum; çünkü eğer faydalanmasını bilirsek çok güzel, lezzetli bir olay; ama elimize gözümüze bulaştırırsak acısı geçmiyor. (Katılımcı 67, erkek, yaş 21).

Muhasebeyi sağlıklı ama tadı kötü yiyeceğe benzetiyorum; çünkü her alanda gerekli ve muhasebe olmadan günlük işlerimiz dahil hiçbir şey yapamayız ama çok sıkıcı. (Katılımcı 98, bayan, yaş 21).

\section{Bilişim Kavramları}

Öğrenciler bu kategoride muhasebe için 4 metafor oluşturmuşlardır. Bu kategorideki metaforlar oluşturulurken öğrencilerin metaforları bilişim kavramlarını dikkate alarak oluşturdukları gözlenmiştir.

Bilişim Kavramları kategorisine bakıldığında 4 metafor 4 başlık altında toplanmıştır. Bunlar Bellek (1), Bilgisayar Programı (1), Bilgisayar (1), Klavye (1). Bilişim Kavramları kategorisine ait bazı öğrenci cevapları verilmiştir.

Muhasebeyi bilgisayara benzetiyorum; çünkü her işlem çok karışık (Katılımcı 13, bayan, yaş 21).

Muhasebeyi belleğe benzetiyorum; çünkü bütün girdi çıktılar kayıt altında tutuluyor. (Katılımcı 118, erkek, yaş 21).

Muhasebeyi bilgisayar programına benzetiyorum; çünkü sistemli ve sistem dışı verileri kabul etmiyor. (Katılımcı 49, erkek, yaş 22).

Muhasebeyi klavyeye benzetiyorum; çünkü siz tuşlara basmadıkça hiçbir zaman yazamıyor. (Katılımcı 41, erkek, yaş 24).

\section{Diğer}

Öğrencilerin muhasebe için oluşturdukları gruplandırılamayan metaforlar bu kategoride toplanmıştır. Bunlar Ders (1), Fabrika (1), Not Defteri (1), Tava (1), Terazi (1), Vazo (1), Reklamlar (1), Umumi Tuvalet (1).

\section{Mali Müşavir Kategorilerinin Analizi}

\section{Kariyer ve Güç}

Öğrenciler bu kategoride mali müşavir için toplam 16 metafor oluşturmuşlardır. Öğrenciler bu kategorideki metaforları oluştururken mali müşaviri kariyer ve güç olarak algılamışlardır. Bunlar Baba (4), Zengin İş Adamı (3), Doktor (2), Usta (1), Baş Öğretmen (1), Genel Müdür (1), Holdingin En Üst Düzeyi (1), Hükümdar (1) Yönetici 
(1), Aslan (1), F -16 (1), Zeki Biri (1), Sert Yapılı (1), Yürüyen Banka, Brad Pitt (1), Holding. Kariyer ve Güç kategorisine ait bazı öğrenci cevapları verilmiştir.

Mali müşaviri babama benzetiyorum; çünkü örnek alınacak adamlar. (Katılımcı 23, erkek, yaş 21)

Mali müşaviri babama benzetiyorum; çünkü tüm evin gelir hesapları onun elinde "Reis". (Katılımcı 33, bayan, yaş 22).

Mali müşaviri babama benzetiyorum; çünkü duruşları çok sert. (Katılımcı 121, bayan, yaş 23).

Mali müşaviri doktora benzetiyorum; çünkü bir sürü bilgileri ve maaşları gayet iyi. (Katılımcı 90, bayan, yaş 20).

Mali müşaviri ustaya benzetiyorum; çünkü alanında kendini iyi yetiştirdiği için. (Katılımcı 7, bayan, yaş 23).

Mali müşaviri aslana benzetiyorum; çünkü çakalları yakalamayı severler. (Katılımcı 109, erkek, yaş 21).

Mali müşaviri hükümdara benzetiyorum; çünkü herşeyin sahipleri sayılırlar, sınırsız paraları var, bir örgütün tüm ipleri onların elinde ister batırırlar ister çıkarırlar. (Katılımcı 84, erkek, yaş 24).

\section{Danışmanlık ve Denetim Kavramları}

Öğrenciler bu kategoride muhasebe için toplam 10 metafor oluşturmuşlardır. Öğrencilerin bu kategorideki metaforları oluştururken mali müşavirin danışmanlık ve denetim görevlerinden etkilendikleri gözlenmiştir. Bunlar Deha (2), Danışman (1), Dadı (1), Denetimci (1), Denetim Altında Tutan Bir Yazılım Programı (1), Hocam (1), Zabıta (1), Tecrübeli Memur (1), Yönetici Kuş (1).Danışmanlık ve Denetim Kategorisine ait bazı öğrenci cevapları verilmiştir.

Mali müşaviri dehaya benzetirim, çünkü anlaşılması zor olan bir şeyi meslek olarak yapıyor. (Katılımcı 26, bayan, yaş 22)

Mali müşaviri dehaya benzetirim, çünkü onları alkışlarım ben. Muhasebeyi anlayıp hem de bayağı ileri seviyeye gelmişler maşallah. (Katılımcı 69, bayan, yaş 20)

Mali müşaviri danışmana benzetirim, çünkü işletmelerin kayıt yaptırırken fikir sahibi olması ve doğru kayıt için yol gösterici. (Katılımcı 77, erkek, yaş 20).

Mali müşaviri dadıya benzetirim, çünkü görevi denetlemek olduğu için. (Katılımcı 78, bayan, yaş 21).

Mali müşaviri denetimciye benzetirim, çünkü gördüğüm kadarıyla denetim yapıp rapor hazırlar, bilirkişi olurlar. (Katılımcı 106, erkek, yaş 23)

\section{Muhasebe Araç ve Gereçleri Kategorisi}

Öğrenciler bu kategoride mali müşavir için toplam 9 metafor oluşturmuşlardır. Öğrencilerin bu kategorideki metaforları oluştururken mali müşaviri muhasebe araç ve gereçleri ile ilişkilendirdiği gözlenmiştir. Bunlar Çok Fonksiyonlu Hesap Makinesi (2), Para Sayma Makinesi (2), Ayaklı Bilgisayar (1), Bilgisayar (1), Büro Takımı (1), Kâğıt (1), Kalem (1). Muhasebe Araç ve Gereçleri Kategorisine ait bazı öğrenci cevapları verilmiştir.

Mali müşaviri çok fonksiyonlu hesap makinesine benzetiyorum, çünkü muhasebeciye göre her konuda daha tecrübeli ve bilgili. (Katılımcı 114, bayan, yaş 21).

Mali müşaviri para sayma makinesine benzetiyorum, çünkü çözümde başka yaptığı bir şey yok. (Katılımcı 10, bayan, yaş 21).

Mali müşaviri para sayma makinesine benzetiyorum, çünkü hayatı para olmuş. (Katılımcı 60, bayan, yaş 21).

Mali müşaviri kâğıda benzetiyorum, çünkü ellerinde hep bir sürü kâğıtla, kitapla gezer. (Katılımcı 48, bayan, yaş 21).

Mali müşaviri kâğıda benzetiyorum, çünkü çeşidi çok. (Katılımcı 47, bayan, yaş 24). 


\section{Gelecek Odaklılık Kategorisi}

Öğrenciler bu kategoride mali müşavir için toplam 9 metafor oluşturmuşlardır. Öğrencilerin bu kategorideki metaforları oluştururken mali müşaviri mesleğini geleceği ile ilişkilendirdiği gözlenmiştir. Bunlar Yeşil Soğan (1), Stajyer Avukat (1), Meyve Veren Ağaç (1), Genç İnsanlar (1), Futbolcu (1), Başarı (1), Çocuk (1), Belgeyi Alınca Statü Atlayan Muhasebeci (1), Acun Ilıcalının Fakir Hali (1). Gelecek Odaklılık Kategorisine ait bazı öğrenci cevapları verilmiştir.

Mali müşaviri yeşil soğana benzetiyorum, çünkü daha belirli sınavlar sonucunda yeni yeni bir yerlere gelmiş, sorumluluğu kendisine ait girişimlerde bulunmuş ve bu işlemler sırasında emek sarf etmiş. (Katılımcı 55, bayan, yaş 25).

Mali müşaviri meyve veren ağaca benzetiyorum, çünkü eğitimleri sonucu güzel, istediği bir şeyi başarıyor. (Katılımcı 80, bayan, yaş 22).

Mali müşaviri stajyer avukata benzetiyorum, çünkü yakında çok para kazanacak. (Katılımcı 35, erkek, yaş 25).

\section{Güven Kategorisi}

Öğrenciler bu kategoride mali müşavir için toplam 12 metafor oluşturmuşlardır. Öğrencilerin bu kategorideki metaforları oluştururken mali müşaviri güven unsuru ile ilişkilendirdiği gözlenmiştir. Bunlar Banka (3), Kasa (3), Memur (3), Ciddi Adamlar (1), Kararlı Birisi (1), Para Kasası (1).Güven Kategorisine ait bazı öğrenci cevapları verilmiştir.

Mali müşaviri kasaya benzetiyorum, çünkü değerli eşyalarınızı kasaya koyarsanız güvende olur. (Katılımcı 19, bayan, yaş 21).

Mali müşaviri kasaya benzetiyorum, çünkü güvenle çok para kazandıklarını düşünüyorum. (Katılımcı 12, bayan, yaş 21).

Mali müşaviri memura benzetiyorum, çünkü çalışma düzeni ve alanı belli kalıplar dışına çıkmaz. (Katılımcı 49, erkek, yaş 22).

Mali müşaviri kararlı birisine benzetiyorum, çünkü başarıya ulaşmış ve daha da başarmak için uğraşan birisidir. Çalışmasının meyvelerini almıştır.(Katılımcı 85, erkek, yaş 22

\section{Mesleki Simgeler Kategorisi}

Öğrenciler bu kategoride mali müşavir için toplam 12 metafor oluşturmuşlardır. Öğrencilerin bu kategorideki metaforları oluştururken mali müşaviri meslek ile ilgili simgelerle ilişkilendirdiği gözlenmiştir. Bunlar Para (6), Kravat (1), Katipler (1), Meyve (1), Robot (1), Sekreter (1), Yol (1). Mesleki Simgeler Kategorisine ait bazı öğrenci cevapları verilmiştir.

Mali müşaviri paraya benzetiyorum, çünkü çok paraları var. (Katılımcı 5, bayan, yaş 21).

Mali müşaviri paraya benzetiyorum, çünkü parayla ilgileniyor. (Katılımcı 30, bayan, yaş 21).

Mali müşaviri robota benzetiyorum, çünkü ne gecesi ne gündüzü var işleri zor be. (Katılımcı 61, bayan, yaş 22).

Mali müşaviri sekretere benzetiyorum, çünkü işletme ile ilgili her türlü işlere koşan birdir. (Katılımcı 14, bayan, yaş 24).

\section{Olumsuz Kavramlar Kategorisi}

Öğrenciler bu kategoride mali müşavir için toplam 27 metafor oluşturmuşlardır. Öğrencilerin bu kategorideki metaforları oluştururken mali müşavirliği kötü metaforlarla ilişkilendirdiği gözlenmiştir. Bunlar Hırsız (2), Cemaate (1), Çakala (1), Davetsiz Misafir (1), Dertli Bir Adam (1), Devreleri Yanmış (1), Donmuş Ödeme (1), Göbekli Adam (1), Gözlüklü Birine (1), Hayattan Zevk Almayan Sadece Para İçin Yaşayan Biri (1), Kasıntı Bir Tipe (1), Kedi (1), Maymun (1), Penguen (1), Para Avcısı (1), Sahetekar (1), diplomalı vergi kaçakçısı (1), SıkıCı Bir 
Meslek (1), Tilki (1), Sırtlan (1), Stres Topu (1), Tefeci (1), Titanik (1), Tahta Kapı (1), İş̧i (1), Masa Başı İşçi (1), Kukla (1). Olumsuz Kavramlar Kategorisine ait bazı öğrenci cevapları verilmiştir.

Mali müşaviri hırsıza benzetiyorum, çünkü sürekli vergi kaçıııyorlar. Aldıkları paranın helal olduğuna inanmıyorum ve kesinlikle muhasebeye yönelmeyi düşünmüyorum. Zaten hep de o dersten kalıyorum. (Katılımcı 42, bayan, yaş 22).

Mali müşaviri hırsıza benzetiyorum, çünkü nankördür.(Katılımcı 115, bayan, yaş 20).

Mali müşaviri hırsıza benzetiyorum, çünkü sömürüyor.(Katılımcı 70, bayan, yaş 21).

Mali müşaviri maymuna benzetiyorum, çünkü kendi bağlı olduğu şirketin menfaati için her türlü uygunsuzluğu yapar. (Katılımcı 43, erkek, yaş 26).

Mali müşaviri penguene benzetiyorum, çünkü gözümde sadece takım elbise giyinmiş sıkıcı biri canlanıyor. (Katılımcı 44, bayan, yaş 21).

Mali müşaviri kuklaya benzetiyorum çünkü onaylama yetkisi yok, gelen işlemi hesaba yükle. (Katılımcı 113, bayan, yaş 21).

\section{Mali Müşavir Kategorilerinin Analizi}

\section{Tecrübe ve Kıdem}

Öğrenciler bu kategoride mali müşavir için toplam 24 metafor oluşturmuşlardır. Öğrencilerin bu kategorideki metaforları oluştururken mali müşaviri tecrübe ve kıdem ile ilişkilendirdiği gözlenmiştir. Bunlar Tecrübeli Akademisyen (5), Ulaşılmaz Biri (2), Daha da Zeki (1), Yaşlı Adam (1), İmam (1), Kıdemli Memur (1), Bilgisayar (1), İsinde Kutsal Memur (1), Kuru Soğan (1), Kül Yutmaz (1), Kütüphane (1), Üst Rütbeli Biri, Şarap, Prestij Abidesi, Rütbe Sahibi, Terminatör, Alanında Uzman, Hint Kumaşı, Yüksek Muhasebeci (1). Tecrübe ve Kıdem Kategorisine ait bazı öğrenci cevapları verilmiştir.

Yeminli mali müşaviri tecrübeli akademisyene benzetiyorum, çünkü belli bir süre muhasebe ile uğraşmış o işin kurdu olmuş birisi olduğu için. (Katılımcı 27, erkek, 21).

Yeminli mali müşaviri şaraba benzetiyorum, çünkü ununu elemiş eleğini asmış oluyorlar artık. Biraz daha fazla para kazanıp daha az iş yapan kısmı olarak düşünüyorum. (Katııımcı 64, erkek, yaş 24)

Yeminli mali müşaviri ulaşıımaz birine benzetiyorum, çünkü ununu elemiş eleğini asmış oluyorlar artık. Olunması gerçekten zor ve sabır gerektiren bir iş parası da ona göre tabi. (Katılımcı 15, bayan, yaş 21).

Yeminli mali müşaviri yaşı adama benzetiyorum, çünkü ununu elemiş eleğini asmış oluyorlar artık. $O$ artık tek ürünün ehli olmuştur. Hemen her şeyi biliyordur.(Katılımcı 39, bayan, 20).

Yeminli mali müşaviri kütüphane benzetiyorum, mali müşavirden daha kapsamlı bilgilere sahiptir. Bir bilgisayara kütüphane kadar bilgilere sahiptir. Bir bilgisayara kütüphane kadar birbirinden farklı işlevler ve bilgileri kapsarlar (Katılımcı 37, bayan, yaş 21).

Yeminli mali müşaviri yaşı adama benzetiyorum, o artık tek ürünün ehli olmuştur. Hemen her şeyi biliyordur. (Katılımcı 39, bayan, yaş 20).

\section{Kazanç ve Zenginlik}

Öğrenciler bu kategoride yeminli mali müşavir için toplam 25 metafor oluşturmuşlardır. Öğrencilerin bu kategorideki metaforları oluştururken yeminli mali müşaviri kazanç ve zenginlik ile ilişkilendirdiği gözlenmiştir. Bunlar Para (8), Para Babası (6), Banka (2), Para Makinesi (2), Banker (1), Fabrika (1), Hayattan Zevk Almayan Daha Zengin İnsan (1), Merkez Bankası (1), Limitsiz Kredi Kartı (1), Acun Ilıcalı (1), Lüks Bir Yer (1). Kazanç ve Zenginlik Kategorisine ait bazı öğrenci cevapları verilmiştir.

Yeminli mali müşaviri paraya benzetiyorum, çünkü çok iyi para kazanıyorlar (Katılımcı 8, bayan, yaş 23) 
Yeminli mali müşaviri para basma makinesine benzetiyorum, çünkü iyi bir yerde imzası bi hayli para ediyor. Aynı zamanda çok iyi bir disiplinle hareket eden, zamanlı planlı insanlar. (Katılımcı 31, bayan, yaş 22).

Yeminli mali müşaviri para basma makinesine benzetiyorum, çünkü baya iyi para alıyorlar. (Katılımcı 61, bayan, yaş 22).

Yeminli mali müşaviri paraya benzetiyorum, çünkü yemin ettiyse para bir gün gelir. (Katılımcı 92, erkek, yaş 22).

Yeminli mali müşaviri paraya benzetiyorum, çünkü adamlar para basıyor. (Katılımcı 106, erkek, yaş 26).

Yeminli mali müşaviri limitsiz kredi kartına benzetiyorum, çünkü çok zengin oluyorlar. (Katılımcı 13, bayan, yaş 22).

Yeminli mali müşaviri fabrikaya benzetiyorum, çünkü para neredeyse ordadırlar. (Katılımcı 34, erkek, yaş 23).

\section{Yetki ve Otorite}

Öğrenciler bu kategoride yeminli mali müşavir için toplam 19 metafor oluşturmuşlardır. Öğrencilerin bu kategorideki metaforları oluştururken yeminli mali müşaviri yetki ve otorite ile ilişkilendirdiği gözlenmiştir. Bunlar Doktor (3), Anne (2), Başbakan (1), Bakan (1), Duvar (1), Enter Tuşu (1), Gözü Dönmüş Deha (1), Hakim (1), Yetkili Kişi (1), Gömlek (1), Holding Sahibi (1), Holding (1), Otoriter Kişi (1), Teknik Direktör (1), Adam (1), Hipnoz Dene Psikolog. Yetki ve Otorite Kazanç Kategorisine ait bazı öğrenci cevapları verilmiştir.

Yeminli mali müşaviri doktora benzetiyorum, çünkü doktorlarda işe başlamadan önce hipokrat yemini ediyorlar. (Katılımcı 90, bayan, yaş 23).

Yeminli mali müşaviri doktora benzetiyorum, çünkü ikisi de sözünde sadık olmalı. (Katılımcı 81, erkek, yaş 24).

Yeminli mali müşaviri anneme benzetiyorum, çünkü koyulan kurallar dışına çıkılmıyor. O ne derse o dur! (Katılımcı 33, bayan, yaş 22).

Yeminli mali müşaviri anneme benzetiyorum, çünkü otoriterdirler. (Katılımcı 96, bayan, yaş 21).

Yeminli mali müşaviri otoriter kişiye benzetiyorum, çünkü diğer mali müşavirlere göre işlerinde daha başarılı ve sorumluluk bilinci yüksek olan kişilerdir. (Katılımcı 14, bayan, yaş 23)

\section{Denetim ve Güven}

Öğrenciler bu kategoride yeminli mali müşavir için toplam 17 metafor oluşturmuşlardır. Öğrencilerin bu kategorideki metaforları oluştururken yeminli mali müşaviri denetim ve güven ile ilişkilendirdiği gözlenmiştir. Bunlar Kasa (3), Güvenilir (2), Zabıta (1), Düzeltmeci Olan Program (1), Avukat (1), Hapis (1), Kasa (1), Yeminin Bozulmayacağı Tek Şey (1), Denetleme (1), Dadı (1), Banka Kasası, Kiralık Kasa, Müfettiş (1), Kola Formülü (1), Kuş (1). Denetim ve Güven Kategorisine ait bazı öğrenci cevapları verilmiştir.

Yeminli mali müşaviri kasaya benzetiyorum, çünkü tek imzası ile bir sürü işi çözüyorlar, her şey onda güvende. (Katılımcı 80, bayan, yaş 22).

Yeminli mali müşaviri zabıta benzetiyorum, çünkü işletmelerdeki usulsüz işlere müşavir defterlerini kontrol eden devlet adına iş yapan kişi. (Katılımcı 77, erkek, 24).

Yeminli mali müşaviri kola formülüne benzetiyorum, çünkü kapattığı defterler içinde ne olduğunu kimse bilmiyor. (Katılımcı 41, erkek, 24).

Yeminli mali müşaviri müfettişe benzetiyorum, çünkü sertler ve sürekli denetimle uğraşıyorlar. (Katılımcı 50, erkek, yaş 23).

\section{Zorlu Süreç}

Öğrenciler bu kategoride yeminli mali müşavir için toplam 8 metafor oluşturmuşlardır. Öğrencilerin bu kategorideki metaforları oluştururken yeminli mali müşaviri zorlu bir süreç olarak algılamışlardır. Bunlar Dünyanın Yedi Harikası (1), Su (1), Saksıdaki Çiçek (1), Müşavirin Biraz Daha Rahatlamış Hali (1), Nikah 
Masasında Evlilik Yemini Eden Çift (1), Vaşak (1), Robot (1), Yönetici (1). Zorlu Süreç Kategorisine ait bazı öğrenci cevapları verilmiştir.

Yeminli mali müşaviri saksıdaki çiçeğe benzetiyorum, çünkü ne kadar ilgi ve şevkat gösterirsen ona göre davranır. (Katılımcı 16, bayan, yaş 23).

Yeminli mali müşaviri saksıdaki çiçeğe benzetiyorum, çünkü ununu elemiş eleğini asmış oluyorlar artık. Biraz daha fazla para kazanıp daha az iş yapan kısmı olarak düşünüyorum. (Katııımcı 64, erkek, yaş 24).

Yeminli mali müşaviri robota benzetiyorum, çünkü maslowun ihtiyaçlar hiyerarşisi açısından baktığımızda kendini gerçekleştirmiştir artık. (Katılımcı 62, bayan, yaş 26).

\section{Olumsuz Kavramlar}

Öğrenciler bu kategoride yeminli mali müşavir için toplam 10 metafor oluşturmuşlardır. Öğrencilerin bu kategorideki metaforları oluştururken yeminli mali müşaviri için olumsuz görüşlerinin ifade etmişlerdir. Bunlar Boş işlerle Uğraşan Biri (1), Canavar (1), Çakallar (1), Çelik Kapı (1), Diktatör (1), Ölü Bir Adam (1), Köle (1), Soyguncu (1), Top (1), Üstüne Beton Dökülmüş Adam (1). Olumsuz Kavramlar Kategorisine ait bazı öğrenci cevapları verilmiştir.

Yeminli mali müşaviri çakallara benzetiyorum, çünkü parayla oynasınlar ve sömürü odaklı çalışırlar. (Katıııcı 73, erkek, yaş 23).

Yeminli mali müşaviri canavara benzetiyorum, çünkü önüne ne gelirse yutar(Katılımcı 70, bayan, yaş 21).

Yeminli mali müşaviri diktatöre benzetiyorum, çünkü katı sert mizaçlı olduklarını düşünüyorum. (Katıımcı 12, bayan, yaş 22).

Yeminli mali müşaviri soyguncuya benzetiyorum, çünkü bir imza ile dünyanın parasını alıyorlar ve işlerinde güven arz edemiyorlar işin her noktasını bilip minimum vergi ödüyorlar ya da anlaştığı işletmeye ödetiyorlar. (Katılımcı 66, erkek, yaş 23).

\section{SONUÇ}

Metaforlar insanların anlatmak istedikleri herhangi bir olay ya da nesne için geliştirdikleri kavramlardır. Insanların anlatmakta zorluk çektiği ifadeleri anlatmakta sıkça kullanılır. Bu çalışmada da muhasebe, mali müşavir ve yeminli mali müşavir için öğrenciler metafor oluşturdu. Toplam 122 öğrenci tarafından 73 metafor geliştirildi. 33 metafor ile muhasebenin en çok ilişkilendirildiği kategori Belirsizlik - Karmaşa Kategorisi oldu. Öğrenciler muhasebeyi çoğunlukla karmaşık bir sistem olarak algılamaktadırlar. Özellikler öğrenci yaşının artıkça bu karmaşanın azaldığı görülmektedir.

Mali müşavir için 122 öğrenciden 105'i 80 anlamlı metafor geliştirmiştir. 27 metafor ile en çok metafor oluşturulan kategori Olumsuz Kavramlar olmuştur. Öğrenciler mali müşavirliğin zor ve güven gerektiren bir süreç olduğunu vurgulamışlardır. Çalışma şartlarının zorluğundan bahsedilmiştir.

Yeminli mali müşavir için 122 öğrenciden 103'ü 78 metafor oluşturmuştur. En çok metafor toplanan kategori 25 metafor ile Kazanç ve Zenginliktir. Öğrenciler yeminli mali müşavirlik için mesleğin yüksek kazanç getirisi olduğunu düşünmektedirler.

Genel olarak bakıldığında öğrencilerin en çok kullandıkları metaforların parasal kavramlar oldukları dikkat çekmektedir. Muhasebenin, mali müşavirin ve yeminli mali müşavirin bir çok görevi ve özelliği olmasına rağmen kilit noktayı parasal kavramların oluşturduğu görülmüştür. Öğrencilerin anketleri doldururken akademisyenlerden ve aldıkları derslerden çok etkilendikleri gözlenmiştir. 


\section{KAYNAKLAR}

Ağca, A., Yalçın, N. (2009) “Muhasebe Mesleğinde Kadın Olmak Bir Sorun Teşkil Eder mi” Dumlupınar Üniversitesi Sosyal Bilimler Enstitüsü sayı 24, s 37

Akdemir, A. (2009) “işsletmeciliğin Temel Bilgileri” Ankara, Ekin Basım Yayın Dağıtım. s 323

Aydoğdu, E. (2008) “ilköğretim okullarındaki öğrenci ve öğretmenlerin sahip oldukları okul algıları ile ideal okul algılarının metaforlar (mecazlar) yoluyla analizi" Yayımlanmamış yüksek lisans tezi, Osmangazi Üniversitesi, Eskişehir.

Çelikten, M.(2006) “Kültür ve öğretmen metaforları” Sosyal Bilimler Enstitüsü Dergisi, Cilt: 2, Sayı: 21, s. 270.

Döş, İ.(2010) "Aday Öğretmenlerin Müfettişlik Kavramına İlişkin Metafor Algıları" Gaziantep Üniversitesi Sosyal Bilimler Dergisi. 9(3):607629.

Eraslan, L. (2011) “Akademik Bakış Dergisi” Sayı:27 Kasım-Aralık 2011 Uluslararası Hakemli Sosyal Bilimler E-Dergisi ISSN:1694-528X iktisat ve Girişimcilik Üniversitesi, Türk Dünyası Kırgız - Türk Sosyal Bilimler Enstitüsü, Celalabat - KIRGıZiSTAN

Ergin, H. (2010) “Muhasebeye Giriş” Dumlupınar Üniversitesi yayınları No:22

Kadakoğlu, Ç. (2008) “Liderlikte Öykünün Önemi” Doğuş Üniversitesi Sosyal Bilimler Enstitüsü, yayınlanmamış Yüksek Lisans Tezi, İstanbul s 10

Kocaman, A.(2003) “Dilbilim Söylemi, Söylem Üzerine” ODTÜ Geliştirme Vakfı Yayıncılık ve İletişim A.Ş. Ankara.

Lakoff, G., Johnson, M. (2005), “Metaforlar: Hayat, Anlam ve Dil” Çeviren Gökhan Yavuz DEMiR, İstanbul: Paradigma Yayıncılık. s 11-15

Metin, M. (2014) “Kuramdan uygulamaya Eğitimde Bilimsel Araştırma Yöntemleri” Ankara, Pegem Akademi Yayınları. s $287-311$

Morgan, G.(1998) "Yönetim ve Örgüt Teorilerinde Metafor" Çeviren Gündüz Bulut, İstanbul: MESS Yayın, s 424

Saban, A. (2008) Educational Administration: Theory and Practice Summer 2008, Issue 55, pp: 459-496 Kuram ve Uygulamada Eğitim Yönetimi Yaz 2008, Sayı 55, ss: 459-496

Sanders, P. (1982) “Phenomenology: A New Way of Viewing Organizational Research, The Academic of management Review p 353-360

Sekman, M. (2002), Kesintisiz Öğrenme, 6.ncı Baskı, İstanbul: Alfa Yayıncılık. s 210

Tamimi, Y. (2005) “Örgüt Kültürünün Metaforlarla Analizi” Yayımlanmamış yüksek lisans tezi, Osmangazi Üniversitesi, Eskişehir.

TEK Ö. B., Özgül, E. (2007) “ Modern Pazarlama IIlkeleri” İzmir, Birleşik Matbaacılık, s 643

Tokat, B., Ergun, D.(2004) “işletmecilik Bilgisi” 6.Baskı, Avcı Ofset, i̇stanbul, s 352

Tutar, H.(2013) “işletme\&Yönetim Terimleri Ansiklopedik Sözlük” Ankara, Detay yayıncılık, s 560

Yalçın, M., Erginer, A. (2012) Journal of Teacher Education and Educators Öğretmen Eğitimi ve Eğitimcileri Dergisi Volume/Cilt 1, Number/Sayı 2, 2012, 229-256

Yıldırım, A., Şimşek, H. (2005) “Nitel Araştırma Yöntemleri” Ankara, Seçkin Yayıncılık, s 75

Yob, I. (2003). Thinking constructively with metaphors. A review of B Thayer-Bacon, 2000. Transforming critical thinking: Thinking constructively. New York. Teachers College Press. Studies in Philosophy and Education, 22:127-138.

Zaltman, G., Zaltman, L. (2008) “Pazarlama Metaforları” Çeviren: Ümit Şensoy İstanbul, Optimist Yayım Dağıtım, s 13-43

Zaltman, G.(2004) “Tüketici Nasıl Düşünür?” A.Semih KOÇ İstanbul, MediaCat Yayınları, s 257

www.tdk.gov.tr Erişim tarihi: 08.12.2014

http://www.temelaksoy.com/metafor-yapmak-sihir-yapmak-gibidir/ Erişim tarihi: 08.12.2014

3568 Sayılı Serbest Muhasebeci Mali Müşavirlik ve Yeminli Mali Müşavirlik Kanunu 